\title{
Moral Certitude and Moral Ambiguity in Bernard Bergonzi's The Roman Persuasion
}

\author{
Frederick Hale \\ University of Stellenbosch \\ profhale@iafrica.com
}

\begin{abstract}
The Spanish Civil War of 1936-1939 received an immense amount of attention in the United Kingdom and elicited various responses from trade unionists, liberal intellectuals, members of the Roman Catholic and other churches, and numerous other segments of the population during that highly politicised decade. Largely overlooked in the extensive historiography of the repercussions of the war on British society are the ways in which British religious communities responded to the perceived crisis for both Christendom and European civilisation generally. In the most detailed study of this aspect, Bernard Bergonzi's fictional reconstruction of 1981, The Roman Persuasion, the dilemma of various members of an English Roman Catholic family are probed and analysed in terms of the conflicting mind-sets of English liberalism and authoritarian conservatism in the tradition of Hilaire Belloc.
\end{abstract}

In the eyes of many Roman Catholics in the United Kingdom, the Spanish Civil War of 1936-1939 posed yet another in a series of crises which marked the so-called "age of anxiety", an era of increasing international political and ideological tensions in Europe which ended only with the outbreak of the bloodiest war in the history of the world. Much of the initial press coverage, especially in the Catholic weeklies (The Tablet, The Catholic Herald, The Catholic Times, and The Universe) was riveted on violent anticlericalism and the devastation of ecclesiastical property. It soon became known that Mussolini's Italy, Hitler's Germany, and Stalin's Soviet Union were providing military aid to the belligerents in Spain, thereby threatening to transform its domestic rebellion into an international war. 
On the broader scene of European, or Christian, civilisation, many Catholic and indeed some non-Catholic observers believed that the Spanish Civil War represented the death struggle the established order, possibly the final act in an historical drama which began with the Protestant Reformation and been continued in the Enlightenment and the French Revolution. In short, not only the future of the Church, but also, and particularly from the viewpoint of those who had been influenced by Hilaire Belloc, the future of Europe, hung in the balance.

English Christians across much of the denominational spectrum responded in various ways to the paroxysm of violence which shook Spain for nearly three years. A war of words was fought in the Catholic, Anglican, and other religious weeklies as their editors, like many of their counterparts in the daily press, took firm stands behind either the Nationalist or the Republican cause. Cardinal Arthur Hinsley founded a Bishops' Committee for the Relief of Distress in Spain in September 1936, and eventually sponsored several ambulances and nutrition schemes in Nationalist territory. Meanwhile, the Evangelical Alliance undertook corresponding work by raising funds for the purchase of foodstuffs and other supplies for Protestants. The Society of Friends, or Quakers, launched its own relief efforts on a nonpartisan and nondenominational basis. Committees of prominent church leaders travelled to Spain to investigate issues of religious freedom and kindred matters. Christians of various persuasions co-operated in 1937 to assist in the evacuation of some 4,000 children from the beleaguered Basque provinces to temporary shelter in the United Kingdom.

For the most part, these endeavours have escaped detailed scholarly analysis, To be sure, Adrian Hastings (1991: 315-317, 325) devoted an aggregate of some three pages to them in his survey of English Christianity in the twentieth century, and in his analysis of Britain and the Spanish Civil War (1997: 169-189) Tom Buchanan included a useful onechapter summary titled "Religion" in which he aptly called this "the least-researched aspect of the British response to the Civil War". The significance of the topic is thus recognised, but it has failed to stimulate more than a minuscule portion of the scholarly inquiry that has been devoted to, for example, the outpouring of literary responses of the late 1930s and early 1940 s to the Spanish conflict.

Arguably one of the most incisive and insightful book-length studies of any major aspect of English Christian responses to the Spanish Civil War was written not as conventional historiography but rather as a fictional reconstruction, namely Bernard Bergonzi's commendable novel of ideas, The Roman Persuasion (1981), a work which has almost entirely escaped scholarly scrutiny apart from initial reviews shortly after its appearance. This relatively brief volume occupies a unique place in what has been written about British Christian responses to the war because it is one of the very few detailed, retrospective accounts of a major dimension of the topic, namely the conflicting positions which Roman Catholics in England took to Franco's insurrection. Accordingly, it merits special consideration in any survey of this body of literature.

Possibly because the Second World War followed hard on the heels of the carnage in Spain and much more directly involved the British public in general, the wave of literary 
creativity which the Spanish conflict stimulated in Britain proved short-lived. That civil war was soon demoted to a very minor theme in English literature. In 1981, however, Bergonzi, then a professor of English at the University of Warwick and a recognised historian of twentieth-century British fiction and poetry with an intimate familiarity with the literary world of the 1930s, ploughed this fallow field afresh and simultaneously highlighted the dilemma into which militant anticlericalism with atrocities committed against considerable numbers of priests and members of religious orders in Spain had thrust many Roman Catholics in the United Kingdom. His first published venture in the realm of imaginative literature, The Roman Persuasion, directly addresses that quandary. Few people could have been better equipped to write a fictional reconstruction of intellectually inclined English Roman Catholics' contemporary reactions to the Spanish Civil War. Born in London of Italian and Irish descent and baptised into the Roman Catholic Church in 1929, Bergonzi remained, by his own account, a moderately active if hardly rigidly orthodox member of it. In an essay published in a symposium titled Why I am Still a Catholic (1982: 108), he acknowledged that although he accepted traditional Catholicism with little questioning early in life, his personal Christianity had eventually "become quite Protestant" in that it involved a generous measure of "private judgement" with regard to the teachings of the Church. "There is a sense, too, in which being a Catholic now is like being a Jew, in belonging to a people and a tradition, rather than upholding a particular set of clearly defined doctrines," Bergonzi concluded. "Such personal ecumenism is, for me, at the moment, a sufficient resting place. " His latitudinarian spirit and rejection of ecclesiastical authoritarianism must be borne in mind when reading The Roman Persuasion, in which this cultivated man of post-conciliar Catholicism describes various English Catholic mentalities, allegiances to ideologies, and degrees of obedience to the doctrines of the church nearly half a century earlier.

Bergonzi relied on numerous sources to construct a spectrum of middle-class reactions to the crisis which violent anticlericalism and other aspects of the conflict in Spain created for adherents of the Church of Rome on English soil. To anyone who has perused The Tablet for the late 1930s, it is evident that Bergonzi drew on it. Moreover, his wife's parents were Bernard and Barbara Wall, the former of whom was a key figure in Catholic intellectual circles during the 1930s and an ardent defender of both Mussolini's political behaviour and Franco's insurgency. A middle-class disciple of Hilaire Belloc and a recent graduate of the University of Oxford, Bernard Wall helped to launch The Catholic Worker in 1935 and was the founding and sole editor of a quarterly review titled The Colosseum. He lived in Italy during the mid-1930s when il Duce was near the summit of his popularity and Italian forces invaded Abyssinia, and he visited Nationalist Spain in 1938, a foray which resulted in a nonfictional descriptive account titled Spain of the Spaniards. The indirect influence of the Walls on The Roman Persuasion is patent. Writing from a conventional, omniscient narrator point of view and employing a generally linear narrative, Bergonzi has created a gallery of characters who embody and, from an artistic viewpoint perhaps too neatly typify, much of the spectrum of responses to the Spanish conflict. One principal character is a pious, elderly widower, Wilfrid Cartwright, who resides in a village in West 
Sussex, where he and his late wife had edited a journal titled the English and Overseas Review. Two of his three "argumentative" adult daughters, Helen, Claire, and Dominica, reside with him. Intellectually inclined to varying degrees, the first two are graduates of the University of Oxford, and the third, though less formally qualified, also reads extensively and advocates theological modernism. Implausibly enough, the conversations of these three young women, their father, and Roman Catholic visitors to their home almost invariably rotate around religious themes. They demonstrate that Roman Catholics can retain their faith and remain on speaking terms while willing to discuss religious views which are not fully compatible. Their considerably younger brother, Crispin, is a recent graduate of the University of Cambridge who volunteers to fight on the Nationalist side, thereby bringing another element of dramatic tension into the plot. Conveniently enough, within a few miles of their home reside or have resided a broad array of Catholic luminaries, ranging from Belloc to the literarily orientated Alice and Wilfrid Meynell to the excommunicated modernist Jesuit George Tyrrell. Their guests also include Wilfrid Cartwright's nephew Martin Tolleybeare, an enthusiastic, single-minded devotee of right-wing régimes in Europe whom Claire Cartwright, an ardent Labourite, calls a "Fascist" and who, having assumed the editorship of the review which Wilfred Cartwright and his late wife had edited for many years, drops the name English and Overseas Review in favour of Res Latina, and Father Giles Matlock, a theologically liberal Dominican who has no little time for Tolleybeare, the husband of his younger sister, for fascist movements, or, ultimately, for Franco's insurgency. The dialogue among members of this gallery of characters, some of them arguably too conveniently stereotypical, provides most of the critical voicing in this novel of ideas, and through it Bergonzi broaches many of the issues underlying the debate in English Catholic circles about the war in Spain or otherwise influencing bourgeois Catholic thinking. Among them, he discusses the incompatibility of fascism and Catholicism, Bellocian distributism, relations between church and state, the extent to which Mussolini's Italy can serve as a model Catholic "integrated" society to be emulated, the causes of anticlericalism in Spain, the reliability of the Catholic weekly press for accurate information about violence against the Spanish clergy in 1936, the question of Basque separatism, the case for maintaining the British policy of non-interference in the war, unacknowledged but nevertheless ever-present anti-Semitism, accusations of general decadence in twentiethcentury Western civilisation, guilt for atrocities in the war, the bombing of Guernica, Jacques Maritain's plea for neutrality, the papal encyclicals Mit brennender Sorge and Non Abbiamo Bisogno. Arguably above all else, The Roman Persuasion is a blistering indictment of the conviction, so obvious in much contemporary Catholic commentary on the Spanish Civil War and embodied particularly in the mind of Martin Tolleybeare, that it could be conceptually reduced to a conflict between the devilish Republican forces and the divinely inspired mission of their Nationalist foes to save Christianity in Spain and, by extension, in Europe generally.

Bergonzi carefully weaves conflicting views on many individual questions into the dialogue, but his own anti-Francoite bias repeatedly comes to the fore; writing more than forty years after the conclusion of the Spanish Civil War, and having witnessed, albeit from 
a distance, both the dire consequences of the Nationalist victory therein for civil rights in Spain and at much closer range the effects of fascist expansionism in much of Europe, it was not a difficult position for him to adopt retrospectively. Bergonzi's obvious purpose was apparently to write history in fictional dress and not to create a highly artistic text, and by his own admission his novel contains serious "literary adequacies". ${ }^{1}$ Much of the language of The Roman Persuasion is stylistically flat and unadorned. Moreover, there is relatively little imaginativeness with regard to such narratorial matters as voicing; the characters tend to be contrived, mechanical instruments rather than realistic human embodiments of the positions they so obviously represent. This novel consequently is the sort of text which is of greater interest to students of twentieth-century British church history than to devotees of modern English literature. But one permeating theme, namely whether the Spanish Civil War was a cut-and-dried ethical issue, especially for contemporary British Roman Catholic observers, or a conflict replete with moral ambiguity, rises above the literary shortcomings of this unfortunately neglected novel. ${ }^{2}$

Before considering the pivotal theme of Martin Tolleybeare's simplistic perception of the Spanish Civil War as a duel between Christianity and evil, it is useful to review examples of various English Christian commentators' penchant for engaging in the same reductionist thinking. It is striking how many of them in those years of anguish saw the highly publicised war primarily as a conflict involving their own long-standing concerns regarding either Spain or Europe in general. For example, intense anti-Marxists and antiFascists emphasised the ideological strife; trade unionists perceived in Franco a threat to the labour movement; some theologians saw it primarily the conflict as essentially one of God vs. Satan. Intimately related to this, some believed that the future of the Roman Catholic Church in Spain was at stake. And Douglas Jerrold (1937: 837), amateur historian, editor, novelist, and disciple of Belloc, perceived it as essentially "a counter-revolution perilously long delayed", an evaluation fully in harmony with his long-standing concern with the decline of traditional European civilisation. And many British Nonconformists emphasised the conflict as in large measure the pivot on which the question of religious freedom in Spain turned. To some Quakers, it was first and foremost an arena of suffering owing to militarism and thus a zone in which they felt called to do charitable work. Rarely did English Christian commentators express a belief that the Spanish Civil War involved a welter of conflicts - social, political, economic, religious. Instead, they almost invariably took a reductionist approach and sought to define its essence in dualistic categories. A sample of these formulae penned by people representing diverse religious identities and political affiliations will richly illustrate this crucial point.

Catholic commentators, at least when writing in periodicals of their denomination or in other contexts in which their religious identity came to the fore, almost invariably couched their definitions of the war in religious and often dualistic spiritual terms. Arnold Lunn, for example, a convert to the Church of Rome, declared in his The Spanish Rehearsal (1937a:137), "Religion rather than economics is the key to the Spanish struggle and religion will determine the issue when the same battle is fought on English soil, " an assertion which also highlights a key anticipatory reason why many Englishmen perceived the war in Spain 
not as a remote phenomenon but rather as one which was particularly germane to the future of the United Kingdom. Writing in The Tablet that year (Lunn 1937b: 506), he partly modified his categorisation to clarify that not only religious but also economic beliefs were involved, calling the war one between Roman Catholic and communist cultures. A few months later, however, Lunn re-emphasised the religious nature of the conflict by professing that the factions in Spain could be compared with the twelfth-century crusaders who sought to wrest control of the Holy Sepulchre in Jerusalem from the Turks. Joseph Keating, S.J. (1936), editor of The Month, announced at the start of the war that the pivotal issue in it was "primarily moral and religious" and pitted "godless tyranny inspired by Marx" against "the Catholicism which is the guardian of civil and political rights as well as of the rights of God". In the Dominican journal Blackfriars, meanwhile, his counterpart, Victor White (1936: 647), agreed that it was "no political issue, no mere fighting against a local insurrection, no mere civil war". Rather, it was a proto- eschatological clash "between Christ and antichrist". Readers of the popular weekly The Universe were told at the beginning of Franco's insurgency that the "rebellion" was "the rising of the Catholic people against those who wish to destroy their Church and them". ${ }^{3}$ Explicitly denying that the war was a clash between fascism and communism, the same editor six weeks later that "the issue is between Religion and Atheism. ${ }^{\text {"4 }}$ And Richard Eccles, in a letter to The Tablet in April 1937, adamantly stated with no less certitude that the clash was between "Christian civilization and militant Atheistic Communism". ${ }^{5}$ These Manichean categories were by no means the exclusive domain of the Right. Bishop Peter Amigo of Southwark, whose diocese south of the Thames included vast numbers of working-class Catholics and who often took positions on social issues close to those of the Labour Party, wrote equally bluntly in 1938 that "those in high places who say the struggle in Spain is between Franco and democracy are wrong. It is a question of God versus the Devil."(Clifton 1987:148)

A generally well-developed fictional character, Tolleybeare is overladen with unsubtle physical signs of his demeanour and religio-political beliefs. This only son of a lawyer is described as a "short and stocky" man with "heavy features and black hair cut short". He has the air of a "young Napoleon" (p. 29). A graduate of the University of Oxford, he has a sister who is a nun in Bolton. His only brother was killed during the Great War. Intellectually inclined in his editorial capacity, he vigorously defends Catholic orthodoxy as well as "causes and positions" associated therewith. Tolleybeare, moreover, is cosmopolitan, speaks several languages, travels frequently to Europe, and generally finds European ways more compatible with his personality than are those of England. One of the few people in his homeland with whom he feels an affinity is Hilaire Belloc. So great is his devotion to this French-born Roman Catholic and anti-modernist that he apparently even apes his selection of clothing, at least in the eyes of the very English Wilfrid Cartwright, whose sartorial preferences are pointedly tweedy and who finds a "certain oddity" and provocativeness in the cut of Tolleybeare's "severe black suit" (p. 31). His politics and desire to add a political dimension to Res Latina also disturb his uncle. Tolleybeare tries to interest him in José Antonio Primo de Rivera, the founder of a new political movement in Spain, without telling him that the movement is the Falange. Res Latina, which Bergonzi 
acknowledges was inspired by The Colosseum, later receives subsidies from the Italian embassy in London, the kind of support which Wall's review is not known to have enjoyed. ${ }^{6}$

Indeed, The Roman Persuasion can profitably be read as a scathing criticism of the consequences of crass interpretations of Belloc by his disciples, a matter which troubled some contemporary observers. Notwithstanding Adrian Hastings' assertion (1991:152) that "Hilaire Belloc represented the dominant Catholic mind [in England] only too well," a perusal of the English Roman Catholic press from that period and the 1930s makes it evident that Belloc also had numerous detractors among his co-religionists. A typical critique of his influence appeared in 1929 in Order, a short-lived Catholic journal which carried noteworthy opinions which swam against the stream of prevailing thought within the church. The anonymous author of this piece acknowledged that English Catholics owed an "immense" debt to Belloc, who had done more than anyone else to invigorate them since John Henry Newman and had left his mark on considerable numbers of younger compatriots. This contemporary critic lamented, however, that "not all the disciples do their masters credit" and thought that some of them, whom he did not identify by name but referred in general terms to "the younger clergy", had distorted Belloc's relatively tempered thought in extravagant forms. Hence, "For many Catholics and for many non-Catholics the teachings of Mr. Belloc, often in a very violent form, are regarded as a new Catholic orthodoxy, which is the last thing Mr. Belloc would desire." Yet part of the fault lay with the master himself. Belloc, in the view of this observer, had never really grown out of the mind-set of the 1890 s when he was seeking to counter British admiration of things German and a widespread view in the late Victorian era that "the downfall of the degenerate Latins" before the ascendant "Teutons" was only a matter of time. Moreover, this critic thought it most unfortunate that Belloc had dispensed with his republican ideology and become an antimodern distributist. ${ }^{7}$

Like many subsequent commentators, this writer took Belloc to task for making untenable generalisations about Germanic folk groups and, with equal zeal, advancing categorical statements about the genius of the "Latin" peoples, who supposedly still evinced an inner unity beneath a veneer of individual nationalisms. "We regard those who can see some mysterious unity in the Spaniards and French and Italians as we regard those who think Germans and English or Americans and English are alike-with wonder and admiration," he wrote with no mean sarcasm, adding that despite the undeniable shared historical legacy of Roman Catholicism spanning the ethnic groups which spoke derivatives of Latin "this "mystagoguery of races calls for more simple faith than we possess." In the minds of some of Belloc's disciples, one result of this crassly dualistic conceptualisation of complex European ethnography was a tendency to excuse the sins of the South while excoriating those of the North. Consequently, as one example thereof, they could "mock magniloquent nonsense in Berlin and be silent when the same rubbish is talked in Rome." At a time when some English political commentators had dismissed Mussolini as a violent dictator while others still admired il Duce he presciently warned that "dangerous nonsense is dangerous nonsense even when spoken by a Fascist." Apart from commenting briefly on the residual strain of anti-Semitism in such works as The Jews, this writer in Order did not 
explore in any depth Belloc's ideas in his critical essay but merely stated that in contrast to the "crankiness" that characterised the opinions of some of his admirers Belloc had generally evinced a generous measure of "solidity", "good sense", and a "feeling for reality". Unfortunately, he added, that master had on occasion allowed his "zeal against corruption, folly, and imbecility" to dominate his perception of parliamentary government and thus interpret it negatively, thereby failing to realise that it, like the monarchy, was human and thus weak and corruptible. This antidemocratic element, the writer regretted, had made a profound impact on his followers at a time when democracy was already imperilled by ideological forces of more brutal stripe. The needed antidote seemed evident:

\begin{abstract}
A little less enthusiasm for the new religion of Fascism, an occasional remembrance that 'Gesta Dei per Francos' is not enough for modern history nor the Pax Romana enough for ancient, a resolve, even if he does not like Lord Lambeth, to admit rather more cordially that Israel is at least as much our ancestral home as Rome or Athens, would gratify some Catholics who are proud of him, who read everything he writes and not once only, and who dislike, unreasonably perhaps, spots in the sun. ${ }^{8}$
\end{abstract}

Much of this critique of the Bellocian legacy, written in the year of Bergonzi's birth, could have been penned by Bergonzi himself, so neatly does it dovetail with his perception of Belloc's disciples. But the master's reputation survived the Spanish Civil War essentially unscathed, at least in the eyes of his followers. On the occasion of his seventieth birthday in 1940, Jerrold (1940:66) could proclaim that "the counter-revolution is today afoot, and is, at long last, gaining ground;" this belated advance into the past, he judged, was "largely, if not entirely, due to Hilaire Belloc."

In an early conversation with his liberal brother-in-law, Father Giles Matlock, the Bellocian disciple Tolleybeare declares his allegiance to uncomplicated patterns of thought. "The human mind is constituted to know, to grasp its object," he enlightens this Dominican intellectual. "All that epistemological hair-splitting was dreamed up by German professors, who were either Protestants or atheists, and were shut up in their studies, cut off from the real world." Sealing his argument, Tolleybeare pronounces that "apart from the sacred mysteries, basic truths are simple" (37).

Tolleybeare reeks not only of epistemological but also moral certitude. So committed is he, at least on the surface, to the teachings of the church that he, all subtlety aside, chooses a Latin manual of moral theology as his bedtime reading. The casuistry of its logic in prescribing rules for personal etbics, not least in the realm of sexual behaviour, particularly appeals to him. Illustrating his obedience to papal teachings on one level, although after four years of marriage Tolleybeare has no desire to create children, the thought that his wife might be violating the dictates of the encyclical Casti Connubii by employing some form of contraception disturbs him.

Underlying his thinking on certain specific issues is a basic commitment to the Bellocian notion of the counter-revolution, a desire to recapture much of the spirit of Catholicdominated Europe prior to the Enlightenment and the French Revolution. Modernity, as manifested in such twentieth-century creations as jazz, is seemingly not for him. On the 
contrary, Tolleybeare longs for the recreation of a pastoral society based on intimacy with the earth. But immediately beneath his anti-modern veneer lies a deep attachment to many of modernity's gifts. He is devoted to one icon of twentieth-century worldliness, the sports car, and drives a Triumph Gloria Southern Cross which, he assures his cousin Dominica, "can pass most other vehicles" (39). This supposed devotee of life in the idealised days of the past does in fact drive his vehicle fast, symbolically overtaking bicyclists on the highway when returning to London. And to that city he is devoted, notwithstanding his contrastive idealising of small towns in Tuscany and Provence where, he believes, "men had been able to live harmoniously with God and each other" and where "life was organic and dignified and fundamentally religious, lived close to the soil and the rhythms of nature." But it is the English capital which is the magnet to this man of steel. To be sure, he feels the "instinctive rightness" of travelling south, i.e. to Europe south of the Alps. Yet London is in his blood. After each trip to the continent, Tolleybeare is "secretly glad to be home, sinking back into the familiar grime and indifference of Megalopolis" (41-42). It is there, too, that he enjoys sexual pleasures with his free-spirited wife, who takes the initiative during intercourse. "How wonderful she was, how free and wanton!" Tolleybeare thinks. "How unlike what they called modest, submissive Catholic womanhood!" (48).

Despite his ethical pomposity, the fabric of Tolleybeare's personal moral standards, Bergonzi reveals, is in tatters, and midway through The Roman Persuasion he begins to unravel. His concupiscence stirred by unwelcome sexual abstinence after his wife abandons their marriage, he enters one urban temple of decadence, a posh cinema in central London, where some of the contradictions within him come to the fore. The music played in the auditorium is a curious amalgam of "popular dance-tunes and crooners' songs", familiar strains of Chopin, Schubert, Liszt, and Rachmaninov. Tolleybeare "detested it and yet it possessed and disturbed him" (105), working its way into his senses. This "Megalopolitan music", in Bergonzi's terms, stimulates enhances the libido which had lured him into the cinema. The newsreel is emblematic of the co-existence of vacuous living and human evil, an unsystematic montage of images of Edward VIII, Joseph Goebbels, a dance marathon, a five-year-old figure skater, and an air-raid on Madrid. The film itself, a banal American romance, similarly elicits a mixed reaction in Tolleybeare. He is "repelled, fascinated, and, despite himself, somewhat aroused" by it. Indicative of the confusion in his mind, the imagery of American sexuality reminds him, oddly enough, of a film he had seen of a Nazi party rally in Nuremberg about a year earlier, an obvious allusion to Leni Riefenstahl's heralded documentary film of 1935 , Triumph des Willens, in which she portrayed the Nazi party congress the previous year in heroic terms (108). Small wonder that when Tolleybeare, having been sexually deprived for several weeks, emerges from the cinema he engages the services of a prostitute. He understands, of course, that he thereby sins, but he also realises that the act will be "quickly repented afterwards" with the cheap grace of the confessional available day and night. Tolleybeare does in fact confess his adultery to a priest at Westminister Cathedral that evening and, to his relief, hears the Ego te absolvo pronounced "as briskly and impersonally as the renewal of a season ticket". He sees no need to change this system, "an efficacious mechanism" for dealing with personal sins (111). 
Before leaving the cathedral, he appreciatively listens to the choir rehearsing for High Mass, ponders the need for "disciplined orthodoxy" to keep more mystically inclined Catholics like his cousin Dominica Cartwright from straying from their faith, and thinks disparagingly about modern "sentimental and humanistic" Christological trends to depict Jesus Christ in more down-to-earth terms as, for example, "the Poor Man of Nazareth" or "Christ the Carpenter". Remorse for having committed adultery that evening seems far from his mind.

In a lengthy conversation with his Labourite cousin Claire shortly after the outbreak of the Spanish Civil War, Tolleybeare shows his political colours with regard to events in Europe. When she suggests that he is becoming a fascist, he does not deny it but suggests that it depends on the meaning of the term. In Italy, Tolleybeare avers, Mussolini was leading "an immensely exciting and promising transformation of society" which offered more hope than the "bogus democracy" of the United Kingdom or the leftist notion of a liberating class struggle. The English fascism of Sir Oswald Mosley, on the other hand, gets no support from him, partly because the British mentality was essentially incompatible with the theatricality and flair which Italian fascism required. German National Socialism Tolleybeare rejects as "pagan and racialistic". With regard to the persecution of Jews, he professes that he is not anti-Semitic but adds that "the Jew can cause problems for ordered societies, because of their insistence on preserving a separate identity for themselves and their international allegiances." Echoing another familiar anti-Semitic mantra, Tolleybeare refers to the prominent position of Jews "in both international finance and international Communism". He defends the Italian conquest of Abyssinia as a means of bringing European civilization to "one of the most barbarous and backward countries in the world" and Hitler's reoccupation of the Rhineland on the grounds that "it was their country, after all" (55-59).

The confrontation between the dualistic assumption that evil was almost exclusively on the Republican side while Franco and the Nationalists were God's instruments for restoring Christianity in Spain and an awareness that atrocities were being committed by both sides occurs most poignantly in a heated conversation which Tolleybeare has with the brother of his estranged wife, the theologically liberal Dominican priest Giles Matlock in London in late 1936, several months before the former makes his first wartime trip to Spain. Tolleybeare is initially adamant that atrocious violence against civilians is exclusively the domain of the "Reds". The scholarly Matlock, on the other hand, seeks to disabuse him of that misapprehension by declaring flatly that "the cause you support is also committing atrocities, in a large and systematic way". He explains that he and his fellow Dominicans "deplore the crimes committed on both sides and long for peace in Spain". Tolleybeare only reluctantly allows that there could be a kernel of truth in allegations of mass executions on Majorca and insists that "the necessary process of cleansing " in one "isolated area" does not make the Nationalist campaign "unjust". He remains convinced that Franco is "not simply fighting a defensive war, but leading a counter-offensive that will establish Catholic integralism throughout Europe" (116-118). 
This pivotal scene is a particularly apt piece of historical reconstruction and entirely relevant to the focus of the present analysis. In 1938 Victor White (1938:440-441), the editor of the Dominican monthly journal Blackfriars, felt compelled to respond to critics who bad repeatedly accused him and his periodical of habitual fence-sitting and adopting a "non-committal attitude towards burning questions of the time". This allegation, he acknowledged, had become especially acute because, in his words, Blackfriars had both refused to "enrol under the banner of General Franco" and declined to "fall into line with some of the 'Left Catholic' periodicals on the Continent by siding with the Spanish Republicans". White did not at that time offer reasons for having steered a via media between these two positions. Instead, he explained that his editorial intention was "to cultivate not neutrality but impartiality". The Dominican editor did not mention any other British periodicals by name, but he evidently felt disillusioned by the partisan captivity of many of them, and he informed readers that he and his colleagues had "no reason to wish to imitate their self-complacency and their exclusiveness of all that does not belong to them or fit in with their schemes and views". Again without specifying the objects of his derision, White made it clear that he regarded the Dominican position as a more mature one than those which prevailed in other quarters. "While so many around us are walking on their hands or clambering like apes from branch to branch of the trees," he wrote with no mean condescension, "we find that we are being sufficiently original in walking straight on, one foot after the other, with our eyes fixed on the road before us."

After Tolleybeare travels to Nationalist Spain in 1937, however, the seemingly secure tapestry of his convictions begins to unravel. As an accredited journalist, he is granted a fifteen-minute interview with Franco, who assures him that he and his allies are fighting "not a Spanish internal foe, but the Russian Communist International" (170). But other encounters in Spain are decidedly less assuring. He learns that far from maintaining a genuinely integrated front against that enemy, the Falangists and the Carlist monarchists are merely co-existing in a strained alliance. In a conversation with him, one Falangist dismisses the Carlists as atavists who long for the restoration of a bygone era of los reyos católicos which can never be restored. Moreover, this informant reveals his belief that Spain has too many priests and would do "quite well" with fewer of them. To Tolleybeare, such anticlerical sentiments are intellectually sensible but nevertheless make him feel "uneasy". It is also unsettling to hear from the mouth of one who could speak with "a particular authenticity" that Falangist Spain would learn from such "modern nations" as Germany and Italy; that conflicted with especially with his hitherto disparaging assessment of the Third Reich (142-144).

Tolleybeare's certitude about the Nationalist cause takes another blow during a conversation with an Irishman, Larry O'Toole, who has fought for the Nationalists in the Irish Brigade but, following its return to Eire, is remaining in Spain hoping to receive six months' pay which Franco owes him. His unit's theoretically "splendid" rôle, he relates, "turned out a bloody shambles". The leader of the Irish Brigade, the embittered O'Toole also discloses, was "an out-and-out crook" whose real motives for fighting in Spain bore no resemblance to those which had been announced, for "whatever [Eion] O'Duffy said about 
defending the Catholic Faith and Christian civilization he was really only interested in number one and in making a big name for himself in Irish politics" (152-153). O'Toole's account of "rifts in the fine unity of the Nationalist cause" troubles Tolleybeare, who realises that they are not something about which he could write in Res Latina.

Another epiphany experience occurs when Tolleybeare visits a German military airfield near Salamanca and thereafter eats lunch with a former Messerschmidt 109 pilot from the Condor Legion, Klaus von Aldenleben. They sip Moselle white wine under wall-mounted portraits of Franco and Hitler. Their conversation and others Tolleybeare has with other German airmen during the same meal illustrate the veracity of the Latin proverb in vino veritas. Martin gains the impression from this German and others seated nearby that they are "contemptuous of the Spaniards". One young officer explains that members of the German army and air force volunteered for service in Spain because they were promoted to higher ranks and received generous salaries and allowances. But above all else, intervention in the Spanish war provided "a very fine opportunity for the practice of battlefield tactics and testing new equipment". This profession disturbs Tolleybeare, who has regarded the Nationalist cause as "spiritual, even sacred, not a superior form of military exercise". More acutely disillusioning is the admission by the same pilot that he and colleagues from the Condor Legion bombed Guernica in a raid conducted at the behest of General Mola, one of Franco's most prominent commanders. This undermines Tolleybeare's previously unshakable beliefs, confirmed by an official statement by the Nationalist Government, that the ancient Basque capital had been destroyed by retreating Basques and that it was merely a "Red propaganda story that Nationalist aircraft had bombed the town". (170, 172-174)

Though partly disillusioned by these revelations, Tolleybeare by no means abandons his larger vision of a restored Christian Europe. In his previously mentioned conversation with Father Giles Matlock, he explains in broad and idealised terms that Christian civilisation comprised "the things that were understood by Augustine and Aquinas and Hildebrand and Joseph de Maistre. That is to say, an integrated, organic social order, based in natural law, which will enable men to live harmoniously with each other, in their proper place, carrying out God's will and realizing their supernatural destinies" (119). He does not discover anything even remotely approaching this foretaste of heaven on his visit to Spain, but there he meets an apostle of a movement which envisages its fulfilment. Werner von Aldenleben, a Catholic intellectual from Munich who is writing a book about the war. In impeccable English, he praises Tolleybeare's Res Latina but disagrees with the belief of some of its writers that Christian culture is essentially something Mediterranean. Von Aldenleben allows that much in German culture is tenebrous and pagan but seeks to convince his English interlocutor that Germany nevertheless belongs in the family of European Christian civilisation. In foreign caricatures, he insists, too much attention has been paid to Prussian dominance. "The truly German spirit is, I insist, Catholic, as we find it in the peoples of the Rhine and the Danube," von Aldenleben explains. He adds that the concept of imperialism is a German "contribution of supreme importance, to the European ideal" and informs Tolleybeare that he fully supports the vision of Austrian chancellor Kurt 
von Schuschnigg to resurrect the Holy Roman Empire. Von Aldenleben addresses the Englishman's initial scepticism: "You can't exclude Germany from your thinking, Tolleybeare,' said von Aldenleben. 'We are at the heart of Europe, and you as a European and Christian thinker must accept Germany. It is we who preserve the Roman idea in its purity.' " He admits that he has reservations about Hitler but also trumpets the achievements of the Third Reich (175-185). Eventually Tolleybeare accepts his invitation to attend a conference held in Munich by the Otto III Circle, a private organisation named after the eleventh-century head of the Holy Roman Empire. En route to Germany, he corresponds from Paris with a co-editor of Res Latina about a submitted manuscript which is "much more sympathetic to German ideals and achievements than the magazine had been in the past". Tolleybeare is interested in seeing this piece, which, his colleague informs him, is the work of one William Joyce, who has left Sir Oswald Mosley's British Union of Fascists (190). The fictional character is identical to the historical Irish-American who emigrated to England as a child and became deeply involved in right-wing movements during the $1920 \mathrm{~s}$ and 1930s as inter alia a co-founder of the National Socialist League and in 1939 began several years of service in the employ of Joseph Goebbels' "Ministry for the Enlightenment of the People", broadcasting pro-Nazi propaganda to the United Kingdom (where he was popularly derided as "Lord Haw-Haw" because of his sneering radio voice), only to be hung for treason in London after the end of the Second World War. (Cole 1964) Bergonzi's message is only too clear: Unbridled sympathy for the reactionary movements can eventuate in extremism of the most dangerous sort. The Roman Persuasion ends with Tolleybeare on his journey to this seemingly logical terminus of his Bellocian convictions about the rechristianisation of Europe as "the train sped on in the falling darkness, into the night, across the plains, through the forests, into Germany" (192).

It can hardly be overemphasised that Bergonzi did not place the responsibility for Tolleybeare's crassly truncated view of the Spanish Civil War on the Roman Catholic Church as such. After all, he points out that some practising English Catholics, especially Wilfrid and Claire Cartwright, took a different stance on the war, and to some extent Claire defended her position on doctrinal grounds. Most of the Roman Catholics in Bergonzi's gallery of characters, especially those who are English, are not disciples of Belloc and neither share his unrestrained enthusiasm for the Roman world nor dream of its reconstruction in the twentieth century. Accordingly, some of them clearly disavow the attitude of certitude which governs Tolleybeare's thinking. Behind this text and shining through it on page after page, especially when voiced by Claire Cartwright and Father Giles Matlock, is Bergonzi's rejection of the doctrinaire mind which refused to recognise the universality of human evil and the consequential ambiguity of many moral questions involving it.

\section{Notes}

1. Frederick Hale Private Archives, Spanish Civil War correspondence, uncatalogued materials, Bernard Bergonzi (Leamington Spa) to Frederick Hale, 24 February 1999. 
2. Notwithstanding its artistic shortcomings, The Roman Persuasion merits detailed consideration as a literary text. To date the most extensive treatment of it is a scathing review which an apparently conservative Roman Catholic scholar wrote of it shortly after the novel was published. See J.M. Purcell, review of Bernard Bergonzi, The Roman Persuasion, The Chesterton Review, VIII, no. 3 (August 1982), pp. 255-261. A balanced and consequently much less vitriolic critical assessment is Marigold Johnson, "Re-reading the Thirties", The Times Literary Supplement, no. 4,068 (20 March 1981), p. 304. See also Gillian Wilce, "Just imagine", New Republic, CI, no. 2609 (20 March 1981),p. 24, and Rosalind Wade, untitled review of The Roman Persuasion in Quarterly Fiction Review, CCIXL, no. 1386 (July 1981), pp. 46-47.

3. "Truth About Spain" (editorial), The Universe, LXXVI, no. 3942 (31 July 1936), p. 12.

4. "The 'Fascist' Allegation" (editorial), The Universe, LXXVI, no. 3948 (11 September 1936), p. 141.

5. Richard Eccles (London) to The Tablet, undated, in The Tablet, CLXIX, no. 5057 (10 April 1937), p. 524

6. Frederick Hale Private Archives, Spanish Civil War correspondence files, uncatalogued materials, Bernard Bergonzi (Leamington Spa) to Frederick Hale, 19 November 2001, and Bernard Bergonzi (Leamington Spa) to Frederick Hale, 17 January 2002.

7. "On the Teaching of Mr. Belloc", Order, I, no. 4 (November 1929), p. 120.

8. "On the Teaching of Mr. Belloc", pp. 121-123.

\section{Works cited}

Bergonzi, Bernard (1981): The Roman Persuasion. London: Weidenfeld and Nicolson. (1982): "Reaching into the Silence". In Robert Nowell, ed., Why I am Still a Catholic. London: Collins.

Buchanan, Tom (1997): Britain and the Spanish Civil War. Cambridge: Cambridge University Press.

Clifton, Michael (1987): Amigo-Friend of the Poor. Leominster: Fowler Wright Books Ltd.

Cole, John A. (1964): Lord Law-Haw-and William Joyce: The Full Story. London: Faber.

Cunningham, Valentine (ed.) (1986): Spanish Front. Writers on the Civil War. Oxford: Oxford University Press.

Hastings, Adrian (1991): A History of English Christianity 1920-1990. London: SCM Press, and Philadelphia: Trinity Press International.

Jerrold, Douglas (1937): "The Military Operations in Spain". The Tablet 169 (5066): 837-839. . (1940): "Hilaire Belloc and the Counter-revolution". The Tablet, 176 (5229): 65-67.

Keating, Joseph (1936): "Civil War in Spain". The Month 168 (866): 106.

Lunn, Arnold (1937a): The Spanish Rehearsal. London: Hutchinson \& Co. . (1937b): "The Unpopular Front". The Tablet 169 (5057): 505-506. . (1937c): "Spanish Fever". The Tablet 170 (5073): 153-154.

White, Victor (1936): "Editorial". Blackfriars 17 (198): 647-649. . (1938): "Extracts and Comments". Blackfriars 19 (219): 440-442. 